\title{
NUSYÛZ ISTERI DAN SUAMI DALAM AL-QURÂN (Sebuah Pendekatan Tematis)
}

\author{
Erman \\ Fakultas Syariah dan IImu Hukum UIN Suska Riau \\ E-mail: erman_gani@yahoo.com
}

\begin{abstract}
Abstrak: This article discusses regarding nusyuz of wife and husband in al-Quran perspective. The discussing is focused on the meaning of nusyuz, kinds of nusyuz, and solution which can apply to solve it. A ccording to al-Q uran, there are three steps that can be used by husband if his wife nusyûz. They are giving advice to wife, aparting bed room, and blowing. Vice versa, when the husband nusyuz, al-Q ur' an gives reference to perform the agreement of peace. When the agreement of peace which offered by the wife is not fulfilled by the husband, then she does not ridha, she can do khulû' or divorce where the wife gives ransom so that her husband divorceher.
\end{abstract}

Kata Kunci: nusyûz, isteri, suami, perkawinan

\section{PENDAHULUAN}

Perkawinan merupakan ikatan lahir batin antara seorang laki-laki dengan seorang perempuan sebagai suami istri untuk membentuk rumah tangga (keluarga) yang bahagia dan kekal berdasarkan Ketuhanan Yang Maha Esa. ${ }^{1}$ Sedangkan Kompilasi Hukun Islam menyebutkan bahwa perkawinan adalah pernikahan, yaitu akad yang sangat kuat atau mitsâqan ghalîzhan untuk mentaati perintah yang bertujuan untuk mewujudkan kehidupan rumah tangga yang sakînah, mawaddah dan rahmah. ${ }^{2}$ 
Kehidupan rumah tangga sakînah, mawaddah dan rahmah bisa diraih bila antara suami isteri menjalankan hak dan kewajibannya dengan baik sesuai ketentuan yang berlaku dalam kehidupan rumah tangga. Suami mesti melaksanakan kewajibannya terhadap isteri dalam bentuk memenuhi kebutuhan isteri baik lahir maupun batin sesuai dengan kemampuan sang suami. Sedangkan kewajiban isteri adalah berbakti lahir dan batin kepada suami dalam batas-batas yang dibenarkan hukum Islam.

Bila seorang isteri atau suami tidak mau melaksanakan kewajibannya sebagaimana layaknya kewajiban dalam rumah tangga, seperti suami tidak mau memperdulikan isterinya, atau isteri tidak mau mentaati suaminya, maka hukum Islam memberikan penjelasan mengenai persoalan tersebut yang dalam al Qur'an dikenal dengan isitilah nusyûz. Tulisan ini membahas mengenai nusyûz dalam perspektif al Qur'an yang meliputi pengertian nusyûz, bentuk nusyûz isteri atau suami menurut al Qur'an dan bagaimana solusi terhadap nusyûz istri atau suami menurut al Qur'an.

\section{PEMBAHASAN}

\section{A yat-ayat al-Q uran tentang $N$ usyûz}

QS. Al Nisa'[4]: 34;

ạ!\$\# @ Òsù \$yJî/ Ïä!\$|ïIYY9\# n?tã cqãBo§qs\% A\%y İ̀ 9\$\#

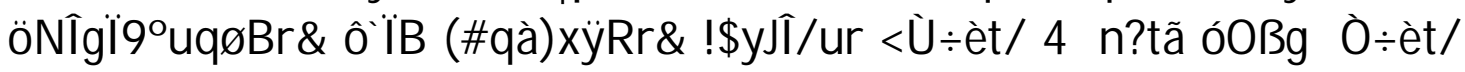

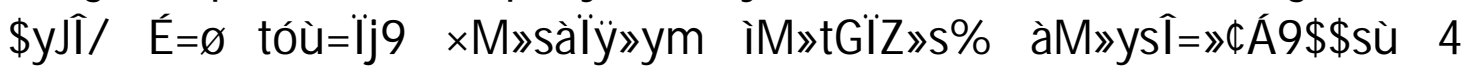

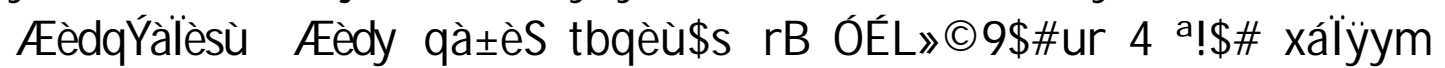

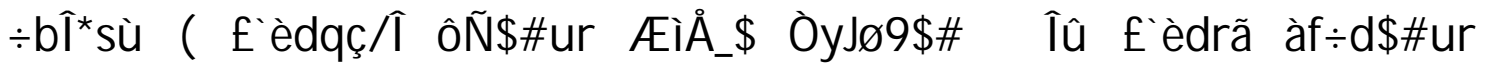

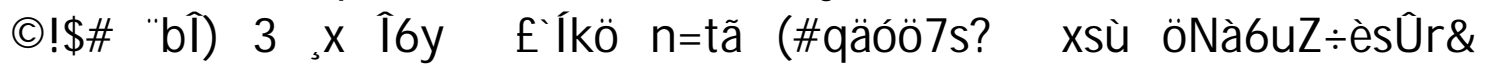
Çİ́̇E \#Z Î6 2 \$w îtã c\%x. Artinya: Kaum laki-laki itu adalah pemimpin bagi kaum wanita, oleh Karena A llah telah melebihkan sebahagian mereka (laki-laki) atas sebahagian yang lain (wanita), dan karena mereka (laki-laki) telah menafkahkan sebagian dari harta mereka. Sebab itu maka wanita yang saleh, ialah yang taat kepada Allah lagi memelihara diri ketika suaminya tidak ada, oleh karena Allah telah memelihara (merkka), wanita-wanita yang kamu khawatirkan nusyûznya, maka nasehatilah mereka dan pisahkanlah mereka di tempat tidur mereka, dan pukullah mereka. Kemudian jika mereka mentaatimu, maka janganlah kamu mencari-cari jalan untuk menyu sahkannya, sesungguhnya A llah $\mathrm{M}$ aha Tinggi lagi $\mathrm{M}$ aha besar. ${ }^{3}$

QS. AI Nisa'[4]: 128;

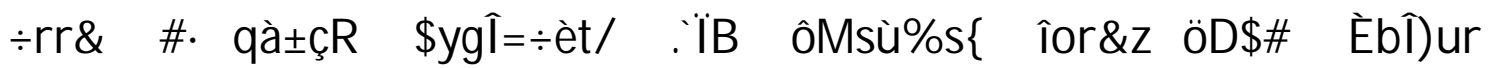

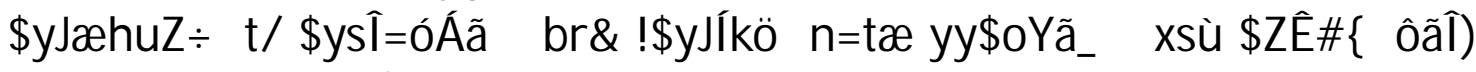
Ú[àÿRF\{\$ İNu AØômé\&ur $3 \times$ ö yz ßxù= Á9\$\#ur 4 \$[sù= $\aleph^{1}$ 


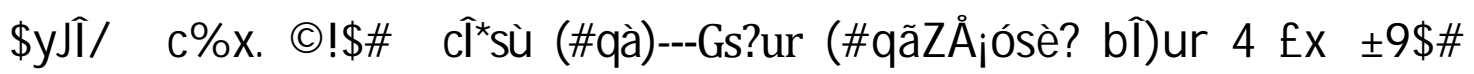
ÇËẼÑ̇ \#Z Î́yz cqè=yJ $\div$ ès?

Artinya: D an jika seorang wanita khawatir akan nusyûz atau sikap tidak acuh dari suaminya, maka tidak mengapa bagi keduanya mengadakan perdamaian yang sebenar-benarnya, dan perdamaian itu lebih baik (bagi mereka) walaupun manusia itu menurut tabiatnya kikir. Dan jika kamu bergaul dengan isterimu secara baik dan memelihara dirimu (dari nusyûz dan sikap tak acuh), M aka Sesungguhnya $A$ llah adalah $M$ aha mengetahui apa yang kamu kerjakan. ${ }^{4}$

Kata الرجل yadalah jamak dari ربل yang secara bahasa berarti laki-laki. ${ }^{5}$ Namun dalam al Qur'an, kata al rijâl memiliki beberapa makna, di antaranya bermakna laki-laki ${ }^{6}$, orang baik (baik laki-laki maupun perempuan), ${ }^{7}$ nabi atau rasul, $^{8}$ ada juga al rajul dalam artian budak. ${ }^{9}$ Sedangkan kata تون secara bahasa berarti النككل بالامر (yang menanggung, bertanggungjawab), atau menjaga dan memelihara. ${ }^{10}$ Departemen Agama menterjemahkannya dengan 'pemimpin'. ${ }^{11}$ Di sisi lain, masih diragukan apakah kata qawâmah bisa diterjemahkan dengan 'pemimpin' dalam bahasa Indonesia. Sedangkan Yusuf Ali sebagaimana dikutip Nasharuddin Umar menterjemahkan ke dalam bahasa Inggris dengan: man are the protector and maintainers of women (laki-laki adalah

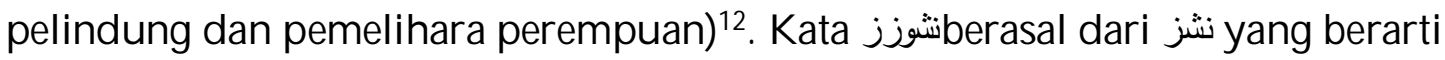
كانن قاعدا| ققام (duduk lalu berdiri) secara bahasa الككان المرتفع (tempat yang tinggi) dan maksud nusyûz dalam ayat

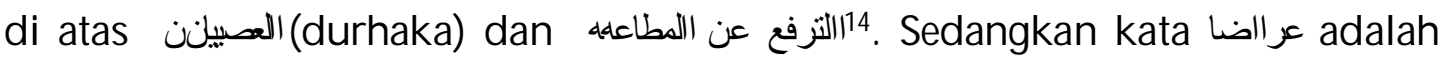
masdar اعرضل yang berarti berpaling. ${ }^{15}$

Asbâb Nuzûl al Âyat (1) QS. Al Nisa'[4]: 34 di atas turun berkenaan dengan seorang Anshar bersama isterinya datang kepada Nabi Muhammad SAW. Si isteri bertanya: "Wahai Rasulullah, ada isteri dari suami Anshar yang bernama fulan bin fulan yang dipukul oleh suaminya sehingga berbekas di wajahnya." Maka Rasulullah bersabda: "Dia tidak berhak berbuat demikian kepada isterinya." Maka Allah SWT. menurunkan ayat QS. AI N isa'[4]: $34 .{ }^{16} \mathrm{QS}$. Al Nisa'[4]: 128 turun berkenaan dengan Saudah binti Zum'ah yang merasa khawatir akan diceraikan oleh Rasulullah SAW, maka dia berkata: "Wahai Rasulullah, janganlah engkau menceraikan saya. Saya akan memberikan satu hari untuk engkau gunakan menggilir Aisyah." Maka Nabi melakukannya, dan turunlah QS. AI Nisa'[4]: 128. Riwayat lain, dari Aisyah bahwa ada seseorang yang memiliki isteri yang sudah tua. Dan dia tidak mau memiliki banyak isteri, maka dia hendak menceraikannya. Kemudian si isteri berkata: "Saya tetapkan sebagian kepentinganku tak perlu kamu penuhi." Maka turunlah QS. AI Nisa'[4]: 128. ${ }^{17}$

Ayat QS. AI Nisa'[4]: 128 dan 34 merupakan ayat madaniyah, karena persoalan hukum merupakan ciri ayat madaniyah dan secara sejarah $\mathrm{Nabi}$ Muhammad tidak menikahi beberapa orang wanita setelah Khadijah wafat kecuali ketika beliau berada di Madinah. 
Dalam al Qur'an kata nasyaza dengan berbagai bentuknya ditemukan dalam al Qur'an sebanyak empat kali, dan dua di antaranya berbicara tentang nusyûz suami dan isteri. ${ }^{18}$

\section{Pengertian N usyûz}

Seperti dijelaskan sebelumnya, nusyûz secara bahasa berarti 'duduk lalu berdiri', atau tempat yang tinggi. Maksudnya adalah sikap tidak patuh dari suami atau isteri. Kata nusyûz berkembang pemakaiannya menjadi kata 'durhaka'. Ibn Manzur dalam kitab Lisân al 'A rab mendefinisikan nusyûz sebagai rasa kebencian salah satu pihak (suami atau isteri) terhadap pasangannya.

Sementara itu Wahbah al Zuhaili memberikan pengertian bahwa nusyûz adalah ketidakpatuhan salah satu pasangan terhadap apa yang seharusnya dipatuhi dan/ atau rasa benci terhadap pasangannya/. ${ }^{19}$

Kompilasi Hukum Islam menjelaskan bahwa seorang isteri dianggap nusyûz bila ia tidak melaksanakan kewajiban utama sebagai seorang isteri yaitu berbakti lahir dan batin kepada suami di dalam batas-batas yang dibenarkan hukum Islam. Isteri mesti menyelenggarakan dan mengatur keperluan rumah tangga sehari-hari dengan sebaik-baiknya/ 20

Sementara itu Departeman Agama RI dalam al Qur'an dan Terjemahannya memberikan definisi nusyûz yaitu meninggalkan kewajiban bersuami isteri, nusyûz dari pihak isteri seperti meninggalkan rumah tanpa izin suaminya. nusyûz dari pihak suami ialah bersikap keras terhadap isterinya; tidak mau menggaulinya dan tidak mau memberikan haknya. ${ }^{21}$

Bila terjadi pembangkangan terhadap sesuatu yang memang tidak wajib ditaati, maka sikap tersebut tidak bisa dikategorikan sebagai nusyûz. Misalnya suami menyuruh isterinya berbuat maksiat kepada Allah SWT. Sikap ketidakpatuhan isteri terhadap suaminya itu tidak berarti isteri nusyûz terhadap suaminya. Atau apabila seorang isteri menuntut sesuatu di luar kemampuan suaminya, lalu suaminya tidak memenuhinya, maka suami tersebut tidak dapat dikatakan nusyûz terhadap isterinya.

\section{Bentuk Nusyủz Isteri dan Suami}

Nusyûz merupakan bentuk permulaan keretakan dalam rumah tangga. Keadaan ini muncul dari salah satu pihak, isteri atau suami yang tidak melaksanakan kewajibannya dengan baik atau salah satu pihak menunjukkan ketidakpatuhannya. Bila ketidakpatuhan itu muncul dari keduanya, suami isteri sekaligus, maka levelnya naik dari nusyûz ke siqâq, sebagaimana dijelaskan dalam QS. AI Nisa'[4]: 129:

ô ÏiB \$VJs3ym (\#qèWyèö/ \$\$sù \$uKÍkÈ] $\div$ t/ s---\$s)Ï@ óOçFøÿÅz $\div$ bî) ur

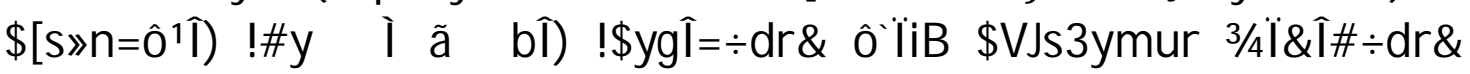

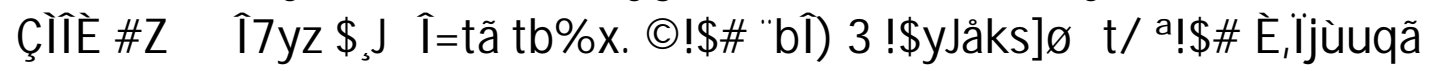


Artinya: D an jika kamu khawatirkan ada persengketaan antara keduanya, M aka kirimlah seorang hakam dari keluarga laki-laki dan seorang hakam dari keluarga perempuan. jika kedua orang hakam itu bermaksud mengadakan perbaikan, niscaya A llah memberi taufik kepada suami-isteri itu. Sesungguhnya Allah M aha $M$ engetahui lagi $M$ aha $M$ engenal.

Pembicaraan tentang syiqâq dalam al Qur'an dijelaskan secara panjang lebar setelah menjelaskan mengenai nusyûz isteri dan solusi yang bisa dilakukan oleh sang suami bila isteri yang bersangkutan melakukan nusyûz.

\section{Bentuk Nusyûz Isteri}

Dasar hukum nusyûz isteri dalam al Qur'an adalah QS. AI Nisa'[4]: 34. Terdapat beberapa ideide al Qur'an di dalam ayat tersebut. Pertama, berbicara mengenai tanggungjawab seorang laki-laki terhadap perempuan dalam rumah tangga; kedua, kriteria seorang isteri yang shalehah yang taat dan melakukan pemeliharaan ketika suaminya tidak ada; ketiga, sikap yang dilakukan oleh suami ketika terjadi nusyûz dari sang isteri.

Ayat tersebut tidak menjelaskan secara rinci batasan-batasan nusyûz seorang istri, namun agaknya kita bisa memberikan pemahaman bahwa nusyûz adalah lawan kata qânut (senantiasa patuh) yang dijelaskan juga dalam ayat tersebut sebelum menyebutkan tentang nusyûz, yaitu

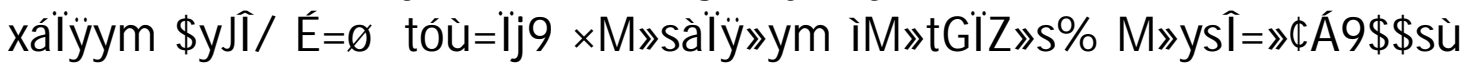

Ayat tersebut menerangkan bahwa 'isteri yang saleh, ialah yang taat kepada Allah lagi memelihara diri ketika suaminya tidak ada, oleh karena Allah telah memelihara (mereka).' Bila dipahami kalimat di atas, berarti isteri yang nusyûz memiliki akhlak yang berbeda atau bertolak belakang dengan akhlak wanita shaleh.

Al Qurthuby dalam tafsirnya menjelaskan bahwa suatu ketika Rasulullah SAW bersabda yang diriwayatkan oleh A bu Hurairah:

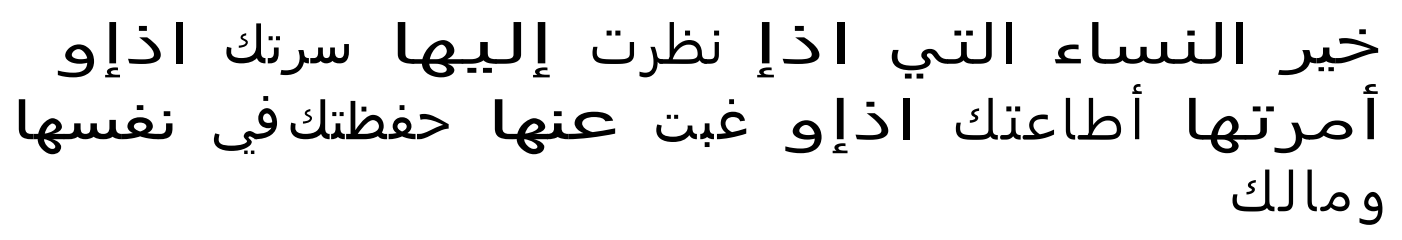

Artinya: Sebaik-baik wanita ialah seorang isteri yang jika kamu memandangnya maka ia menyenangkanmu, jika kamu menyuruhnya dia mentaatimu, jika kamu tidak ada ia menjaga dirinya untukmu dan menjaga hartamu.

Setelah Rasulullah SAW berkata demikian, kemudian beliau membaca QS. AI Nisa'[4]: 34 dari awal ayat sampai selesainya. ${ }^{22}$ Perkataan Rasulullah tersebut memberikan gambaran bagaimana posisi seorang isteri terhadap suami di dalam rumah tangga.

Banyak hadis yang menjelaskan bagaimana pentingnya kepatuhan seorang isteri terhadap suaminya, seperti hadis tentang penolakan seorang 
isteri terhadap suaminya di atas 'tempat tidur' dan sang isteri enggan, maka malaikat akan melaknat sang isteri hingga terbit fajar. Hadis tersebut lengkapnya sebagai berikut:

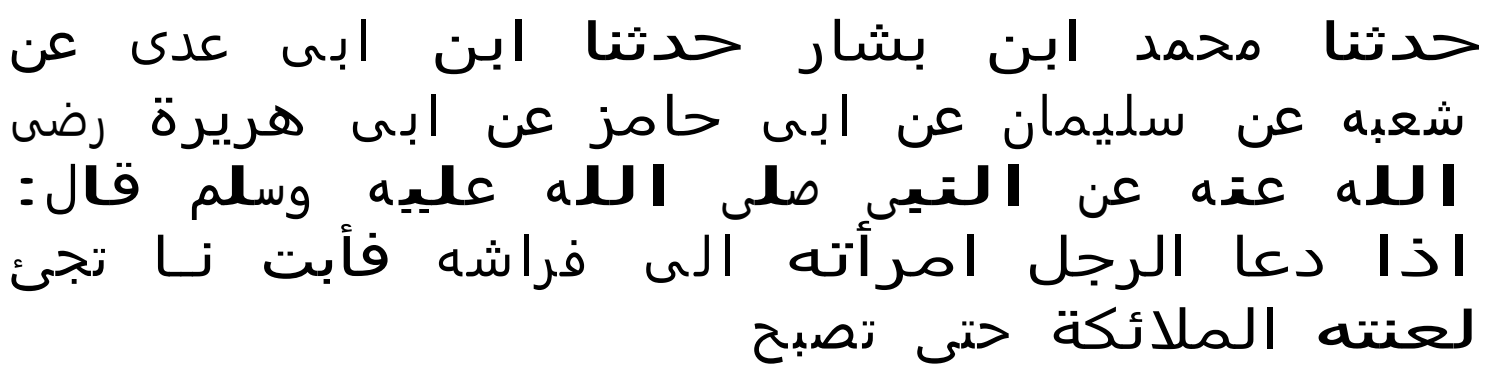

Artinya: M uhammad Ibn Basysyar telah membicarakan kepada kami, Ibn A bi A da' membicarakan kepada kami dari Syu'bah dari Sulaiman dari A bi Hazam dari Abu Hurairah ra. dari Nabi Saw. Bersabda: A pabila seorang laki-laki mengajak istrinya ke tempat tidur, maka sang istri enggan untuk mendatangi ajakan suami maka malaikat akan melaknat sang istri hingga fajar. ${ }^{23}$

Dalam konteks hadis di atas, Imam al-Syafi'i menjelaskan bahwa laknat malaikat itu terjadi jika penolakan istri dilakukan tanpa adanya alasan yang dibenarkan syara' (bi al-ghair 'uzrin syar'iyyin). Mustafa Muhammad Imarah juga berpendapat bahwa laknat itu terjadi jika penolakan istri dilakukan tanpa alasan yang dibenarkan syara. Demikian juga menurut Wahbah al-Zuhaili, laknat di dalam hadis di atas harus diberi catatan selagi istri dalam keadaan longgar dan tidak takut disakiti. Keharusan istri melayani keinginan suami dapat dibenarkan kecuali dalam keadaan sedang mengerjakan kewajiban yang tidak bisa ditinggalkan. Penolakan istri juga dapat dibenarkan apabila dia merasa akan dizalimi oleh suaminya. ${ }^{24}$

Bahkan, lebih tegas lagi al-Syirazi mengatakan bahwa meskipun pada dasarnya istri wajib melayani permintaan suami, tetapi jika memang tidak terangsang untuk melayaninya, ia boleh menawarkan atau menangguhkan sampai batas tiga hari. Adapun bagi istri yang sedang sakit atau tidak enak badan, tidak wajib baginya untuk melayani ajakan suami sampai sakitnya hilang. ${ }^{25}$

Sesungguhnya, ketaatan seorang isteri kepada suaminya didasarkan pada keadaan di mana seorang suami berada pada posisi pemberi nafkah dalam rumah tangga, termasuk juga kelebihan-kelebihan laki-laki terhadap perempuan. Kelebihan-kelebihan tersebut terletak pada mahar, waris, kekuatan, wali, saksi, dalam ibadah, dan lainnya. ${ }^{26}$

Ibn Katsîr menjelaskan bahwa wanita yang nusyûz adalah wanita yang mengadukan hal ihwal suaminya kepada orang lain, menolak perintahnya, berpaling dari suaminya, dan membuat suaminya marah. ${ }^{27}$

Jika seorang istri tidak melakukan kewajiban semisal shalat, atau melakukan keharaman seperti tabarruj (berpenampilan yang menarik perhatian lelaki lain), maka seorang suami wajib memerintahkan istrinya untuk melaksanakan kewajiban dan meninggalkan keharaman tersebut. Jika tidak mau, berarti dia telah melakukan tindakan nusyûz. Dalam kondisi seperti ini, 
seorang suami berhak untuk menjatuhkan sanksi kepada istrinya. Dia juga tidak wajib memberikan nafkah kepada istrinya. Jika istrinya telah kembali, atau tidak nusyûz lagi, maka sang suami tidak berhak lagi untuk menjatuhkan sanksi kepada istrinya, dan pada saat yang sama dia pun wajib memberikan nafkah istrinya.

Ada pendapat lain yang mengatakan bahwa ketika syariat telah menetapkan hak seorang suami secara umum untuk memerintahkan istrinya melakukan sesuatu, atau melarangnya, syariat juga telah men-takhshîsh beberapa hal dari keumuman tersebut. Misal nya, syariat membolehkan seorang wanita untuk melakukan transaksi bisnis, mengajar, melakukan silaturahmi, pergi ke masjid, menghadiri ceramah, seminar, ataupun kajian. Dengan adanya takhshîsh ini, konteks nusyûz tersebut bisa lebih dideskripsikan sebagai bentuk pelanggaran seorang istri terhadap perintah dan larangan suami, yang berkaitan dengan kehidupan khusus (al-hayâh al-khâshah), dan kehidupan suami-istri (al-hayâh az-zawjiyyah).

Di luar semua itu tidak dianggap nusyûz. Artinya, hal-hal yang berkaitan dengan kehidupan umum (al-hayâh al-' ammâh), seperti jual-beli di pasar, atau belajar di masjid, dan hal-hal yang tidak ada kaitannya dengan kehidupan suami isteri tidak termasuk dalam kategori nusyûz. Jika suami memerintahkan istrinya menyiapkan makanan untuknya, menutup aurat di depan laki-laki lain, memerintahkannya shalat, puasa, mengenakan pakaian tertentu, atau tidak membuka salah satu jendela, tidak menjawab orang yang mengetuk pintu, tidak duduk di beranda rumah, tidak mencuci pakaian suaminya, keluar rumah dan lain-lain yang berkaitan dengan kehidupan khusus, atau kehidupan suamiistri, maka syariat telah memerintahkan seorang istri untuk mentaati suaminya dalam perkara-perkara tersebut. Jika dia melanggar dan tidak mentaatinya, maka dia layak disebut melakukan nusyûz, dan kepadanya berlaku hukum nusyûz.

Dalam hal-hal yang tidak terkait dengan kehidupan khusus (al-hayâh alkhâshah) dan kehidupan suami-istri (al-hayâh az-zawjiyyah), maka suami hanya berkewajiban untuk memerintahkan istrinya, atau melarangnya; jika istrinya tidak mau menaatinya, maka tidak bisa dianggap nusyûz. Jika seorang suami, misalnya, memerintahkan istrinya menunaikan ibadah haji, membayar zakat, berjihad, bergabung dengan salah satu partai (organisasi), atau melarang istrinya mengunjungi kedua orangtuanya, bersilaturrahmi dengan kerabatnya, membuka kios untuk berdagang, datang ke masjid untuk shalat berjamaah, menghadiri seminar, tabligh akbar, masirah dan sebagainya, yang berkaitan dengan kehidupan umum (al-hayâh al-'ammâh), dan tidak berkaitan dengan kehidupan khusus atau kehidupan suami-istri, maka seorang istri tidak wajib menaati suaminya dalam perkara-perkara tersebut; sekalipun tetap wajib meminta izin kepada suaminya. Hanya saja, adanya izin tersebut tidak mengikat. Ketika seorang istri tidak menaati suaminya dalam hal seperti ini, maka dia pun tidak bisa dianggap nusyûz. ${ }^{28}$ 


\section{Bentuk N usyûz Suami}

Dasar nusyûz suami dalam al Qur'an QS. AI Nisa'[4]: 128. Berbeda dengan QS. AI Nisa'[4]: 34 tentang nusyûz isteri, nuzyuz suami di sini ditambah dengan istilah i'râd. N usyûz pihak suami kepada isteri lebih banyak berupa kebencian atau ketidaksenangan terhadap isterinya, sehingga suami menjauhi dan tidak memperhatikan isterinya. Selain istilah nusyûz pihak suami, ada juga istilah i'râd (berpaling)/ Perbedaannya adalah jika nusyûz suami menjauhi isteri, sedangkan i'râd suami tidak menjauhi isterinya melainkan hanya tidak mau berbicara dan tidak menunjukkan kasih sayang kepada isterinya. Dengan demikian setiap suami nusyûz pastilah i'râd, sedangkan suami i'râd belum tentu nusyûz.

\section{Solusi Isteri dan Suami Nusyûz Solusi Nusyûz Isteri}

Firman Allah SWT bahwa wanita-wanita yang kamu khawatirkan melakukan nusyûz, yakni wanita-wanita yang dikhawatirkan berbuat nusyûz kepada suaminya, di antaranya mengadukan hal ihwal suaminya kepada orang lain, menolak perintahnya, berpaling dari suaminya dan membuat suaminya marah, jika tanda-tanda itu terlihat, maka nasihatilah dan ingatkanlah akan siksa Allah lantaran dia mendurhakainya, karena Allah SWT telah mewajibkan isteri untuk taat kepada suaminya, karena ketaatan itu merupakan hak sang suami, dan Allah mengharamkan kepada wanita mendurhakai suaminya karena suami itu memiliki keutamaan dan keunggulan atas isterinya. ${ }^{29}$

Bila suami melihat tanda-tanda seorang isteri nusyûz, maka al Qur'an memberikan solusi seperti termaktub dalam ayat itu sendiri:

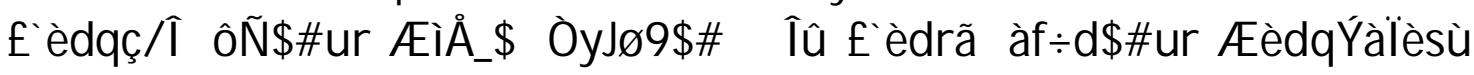

Ayat di atas menjelaskan tahapan-tahapan penyelesaian isteri nusyûz

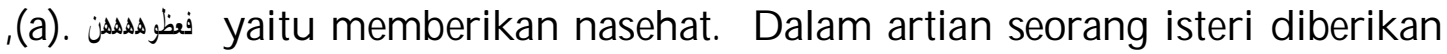
bimbingan, petunjuk dan peringatan tentang ketakwaan kepada Allah SWT serta hak dan kewajiban suami isteri dalam rumah tangga. Nasehat kepada isteri yang nusyûz harus dilakukan dengan cara bijaksana dan lemah lembut. A pabila dengan cara lemah lembut tidak dapat merubah sikap nusyûz isteri maka suami diperkenankan untuk mengancam isteri nusyûz itu dengan menjelaskan bahwa sikap nusyûz seorang isteri terhadap suaminya, dapat menggugurkan hak-hak isteri atas suaminya.

Sementara itu al Qurthuby menjelaskan bahwa makna dari نفولهas itu adalah بكتابب اله artinya mengingatkan kepada isteri bahwa Allah telah mewajibkan atas mereka untuk bergaul dan berbuat baik terhadap suami, dan bagaimana kemuliaan yang didapatkan seorang isteri atas perbuatannya. ${ }^{30}$ Untuk memberikan penjelasan bagaimana patuhnya seorang isteri terhadap suami, al Qurthuby mengutip beberapa buah hadis, di antaranya sebagai berikut: 


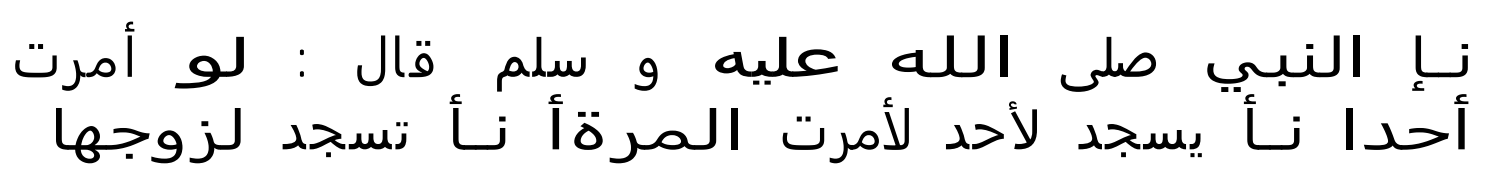

Artinya: Jikalau seseorang diperintahkan sujud kepada orang lain, niscaya aku perintahkan seorang isteri sujud terhadap suaminya. ${ }^{31}$

Kemudian al Qurthuby juga mengutip hadis tentang laknat malaikat terhadap isteri bila menolak ajakan suaminya ke tempat tidur sebagaimana dijelaskan sebelumnya. Agaknya, inilah tema-tema yang disampaikan oleh suami dalam memberikan nasehat terhadap isteri yang nusyûz. Penyampaian hadis di atas oleh al Qurthuby bukanlah dalam artian isteri seolah-olah menjadi budak bagi suami, sebab hadis tersebut maknanya tidak seperti zhahir teksnya, tapi dalam rangka memberikan gambaran mengenai kewajiban seorang isteri

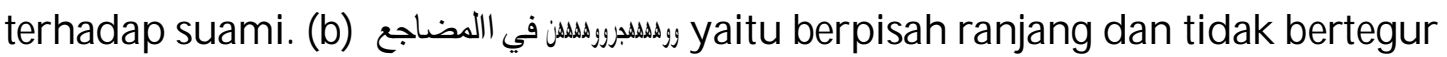
sapa. Tahap ini adalah tahap lanjutan, yakni jika tahap pertama tidak dapat merubah sikap nusyûz isteri. Khusus mengenai tidak bertegur sapa hanya diperbolehkan tiga hari tiga malam, berdasarkan hadis Rasulullah SA W: "Tidak halal bagi seorang muslim untuk tidak bertegur sapa dengan saudaranya lebih

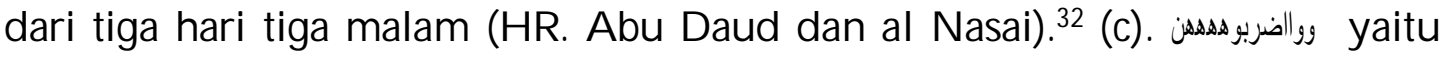
memukul isteri yang nusyûz, namun dengan pukulan yang tidak sampai melukainya. Menurut Muhammad Ali A shâbuni dan Wahbah al Zuhaili, ketika melakukan pukulan harus menghindari bagian muka, karena muka bagian tubuh yang paling dihormati, bagian perut dan bagian tubuh lainnya yang dapat menyebabkan kematian karena pemukulan ini bukan bermaksud mencederai apalagi membunuh isteri yang nusyûz melainkan untuk merubah sikap nusyûz-nya. Memukul hanya pada satu tempat karena akan merubah rasa sakit dan akan memperbesar kemungkinan timbulnya bahaya. ${ }^{33}$ Dalam memukul Mazhab Hanafi menganjurkan agar menggunakan alat berupa sepuluh lidi atau kurang dari itu, atau dengan alat yang tidak sampai melukai. Hal ini berdasarkan hadis dari Rasulullah SAW: Tidak dibenarkan salah seorang kamu memukul dengan pemukul lebih dari sepuluh lidi kecuali untuk melakukan hal yang telah ditetapkan Allah SWT. (HR. Bukhari dan Muslim) ${ }^{34}$. (d) Tahapan keempat ini sesungguhnya tahap yang diberikan untuk menyelesaikan persoalan siqâa, namun demikian apabila tahap pertama, kedua dan ketiga tidak berhasil sementara nusyûz isteri telah menimbulkan kemarahan suami dan menjurus kepada siqâq maka diperlukan juru damai, sebagaimana yang disebutkan Allah dalam QS. al Nisa; [4): 129.

\section{Solusi Nusyûz Suami}

Suami nusyûz bisa diselesaikan dengan cara melakukan perdamaian, seperti disebut ayat:

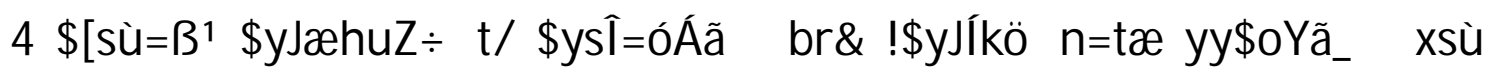
$x \ddot{0}$ yz ßxù= Á9\$\#ur 
A pabila seorang wanita khawatir akan kedurhakaan suaminya, yaitu bersikap congkak padanya, tidak suka kepadanya, dan tidak acuh padanya, maka dalam kondisi seperti ini sebaiknya diadakan perbaikan di antara mereka berdua, dengan cara menggugurkan haknya yang wajib atas suaminya agar ia tetap bersama suaminya itu, yaitu rela dengan lebih sedikit dari yang seharusnya berupa nafkah, pakaian, tempat tinggal atau pembagian hari dengan cara menggugurkan haknya atau memberikan jatah hari atau malamnya kepada suaminya atau kepada madunya. Bila mereka berdua telah sepakat dengan kondisi seperti itu, maka tidaklah berdosa dan tidak salah mereka berdua melakukan itu. Tidak mengapa bagi suami dan tidak mengapa pula bagi isteri. Karena itu suaminya boleh tetap bersama isterinya tersebut dalam kondisi seperti itu, dan itu lebih baik daripada bercerai, itu maksud dari kalimat اولصلح خير (dan berdamai itu lebih baik).

Dari keumuman lafaz ayat dapat diambil kesimpulan bahwa perdamaian antara dua orang yang masing-masing mempunyai hak atau perselisi han dalam perkara apapun, adalah lebih baik daripada masing-masing dari mereka berdua itu saling ngotot dalam mempertahankan hak-haknya, karena dengan berdamai akan menjadi tenang dan tetap berada dalam suasana saling mencintai serta sama-sama memakai sifat toleransi dan saling memaafkan.

Perbuatan tersebut boleh dalam segala perkara, kecuali dalam perkara menghalalkan yang haram atau mengharamkan yang halal, karena sesungguhnya hal itu bukanlah merupakan suatu perdamaian, akan tetapi menjadi sebuah tindakan melampaui batas.

Ibn Katsir menambahkan bahwa firman Allah SWT tentang: 'Perdamaian adalah lebih baik', yakni damainya si isteri dengan mengabaikan beberapa haknya yang wajib diberikan oleh suaminya dan penerimaan suami atas pemberian isterinya itu adalah lebih baik daripada perceraian secara total, sebagaimana Nabi tetap mengawini Saudah bin Zum'ah. Nabi melakukan hal demikian supaya umatnya menjadi akrab terhadap berlaku dan bolehnya praktik tersebut. Jadi praktik itu lebih baik bagi Nabi. Tatkala kerukunan lebih dicintai oleh Allah daripada perceraian, maka Allah berfirman: "Perdamaian itu lebih baik. " dan perceraian itu dibenci Allah SWT. ${ }^{36}$

Bila perjanjian damai yang ditawarkan oleh sang isteri tidak juga dipenuhi oleh sang suami, di mana suaminya tetap memperlihatkan sikapsikap nusyûz-nya, kemudian isterinya tidak ridha, maka ia bisa menempuh jalan khulû', di mana secara bahasa berarti 'menanggalkan'. Hal ini diartikan demikian karena antara suami isteri laksana pakaian antara yang satu dengan lainnya. ${ }^{37}$ Sedangkan secara istilah khulu' adalah perceraian antara suami isteri dengan memberikan tebusan kepada pihak suami dengan ucapan thalâk atau khul $u^{\prime}$. Sedangkan menurut I bn Rusyd, khulû' adalah isteri memberikan tebusan agar suami menceraikannya. ${ }^{38}$

\section{SIMPULAN}


Secara umum dapat disimpulkan bahwa nusyûz adalah kedurhakaan salah satu pihak (suami atau isteri) dalam rumah tangga. Perbuatan nusyûz tersebut bisa dilihat dari sikap yang diperlihatkan oleh masing-masing pihak terhadap pasangannya. Solusi atas nusyûz tersebut bisa diselesaikan oleh kedua belah pihak berdasarkan kesepakatan dan tindakan-tindakan yang dibenarkan Islam.

Terdapat perbedaan solusi yang disampaikan al Qur'an dalam menyelesaikan nusyûz isteri dan suami. Bila yang nusyûz isteri, maka al al Qur'an memberikan tiga tahapan, yakni memberikan nasehat, pisah tempat tidur dan dengan pukulan. Sedangkan bila nusyûz dari pihak suami, maka al Qur'an memberikan acuan diadakannya perjanjian, di mana sang isteri rela mengurangi hak atas suaminya. Agaknya, perbedaan ini terjadi karena berbedanya fungsi suami dan isteri dalam rumah tangga.

Nusyûz merupakan awal dari pertengkaran dalam rumah tangga, bila perselisihan itu terjadi oleh kedua belah pihak secara terus menerus, maka hal itu disebut dengan siqâq.

\section{Endnotes:}

Definisi perkawinan menurut U ndang-undang No. 1Tahun 1974

2 Kompilasi Hukum Islam, Pasal 2 dan 3, Lihat: Abdul Gani Abdullah. 1994. Pengantar Kompilasi H ukum Islam D al am Tata H ukum Indonesia. Jakarta: Gema Insani Pers. hlm. 78.

3 Departemen Agama RI. 1977. al Q ur'an dan Terjemahannya. Jakarta: Bumi Restu. hlm. 123 Ibid. hlm. 128

Ahmad Warson Munawwir. 1997. al M unawwir. Surabaya: Pustaka Progressif, hlm. 479 Seperti dalam QS. AI Nisa'[4]: 32 dan 34 tentang pembagian warisan.

QS. al A'raf[7]: 45;

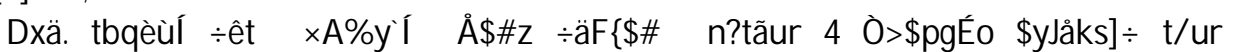

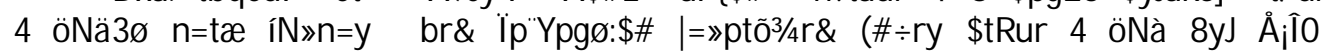

$8 \quad$ QS. al A nbiya'[21]:7

Çî̈E tbqãèyJôÜt öNèdur \$ydqè=äzô $t$ óOs9

(\#pqè= «ó́sù ( öNÍkö s9î) ûÓÇrq R Zw\%y`í wî) $n=0 ̈ 6 s \%$ \$uZù=y ö r\& !\$tBur

9 QS. al Zumar[39]: 29; ÇĐE cqßJn=:ès? w óOçFZä. bî) İ ò2İ̈\%!\$\# @

\$VJn=y Wxã u ur tbqÝ¡Å3»tttFãB âä!\%x.u ào Ïm Ïù Wxã § WxsWtB a

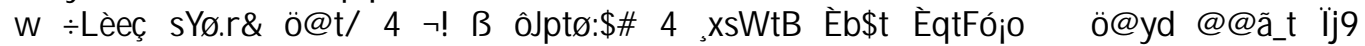

10 Muhammad Ali al Shâbuni, 0 p.cit., hlm. 462 . A tau lihat juga: Al-Thabari, A bû Ja'far Muhammad bin Jarîr. 1978. Tafsîr al-Thabariy. juz 4.Beirut: Dâr al-

Fikr.

11 Depag RI. loc.cit.

12 Lihat: Nasaruddin Umar. 2001. Argumen Kesetaraan Jender Perspektif al Qur'an. Jakarta: Paramida. hlm. 279

13 Munawwir, op.cit., hlm. 1418

14 Muhammad Ali al Sâyis. 2001. Tafsîr A yât al Ahkâ. Beirut: Dâr al Ihya' al Turat al 'Arabi. hkm. 319

15 Munawwir, op.cit. hlm. 918 
Muhammad Ali al Shâbun. 1997. Rawâi'ul Bayân Tafsîr A yât al Ahkâm min al Qur'a. Beirut: Daar al Ihya. hlm. 466

17 Lihat: Ibn Katsîr. tt. Tafsîr AI-Q uran al-Azîim. Beirut: Dar al-Andalus.

18 Fath al Rahman li Thâlib al Q ur'an. tt: Indonesia. Maktabah Dahlan. hlm. 435

19 Wahbah al Zuhaili. 1984. Fiqh Islâm wa A dillatuhu. juz. IX Damsik: Daar al Fikr. hlm. 6855

20 Kompilasi Hukum Islam, Pasal 83 dan Pasal 84.

21 Depag RI, 0 p.cit., hlm. 123

22 Al-Qurthubiy, A bu Abdillah al-A nshariy. tt. Jami` al-A hkam al-Q uran. jilid 8 Kairo: Ar alKutub al-A rabiy. hlm. 161

23 Imam Bukhari. Kitâb al N ikâh bâb Izâ Bâtat al M ar'ah al M uhâjirah Firâsy Zaujihi, hadits nomor 5194, op.cit., jilid V, halaman 479-480.

24 Mustafa Imarah. tt. Jawâhir al-B ukhâri. Surabaya: Maktabah al-Hidayah. hlm. 338: lihat juga: Wahbah al-Zuhali. 1989. Figh al-Islâm wa A dilltuhu. Beirut: Dar al-Fikr. hlm. 335

25 A bu Ishaq al-Syirazi. tt. al-M azâhib fi Figh al-Imâm al-Syafi'i. Beirut: Dar al-Fikr, hlm 65.

26 Al Qurtuby, op.cit., hlm.161

27 Ibn Katsir, Op.cit., hlm. 292

28 http:/ / www.aliisright.com/ details.asp?id=41

29 Ibn Katsir, loc.cit.

30 Al Qurtuby, op.cit., hlm. 161.

31 Ibid.

32 Wahbah al Zuhailid, loc.cit.

33 Muhammad al Shâbuni, loc.cit, Wahbal al Zuhaili, loc.cit

34 Ibid

35 Ibn Katsir, loc.cit.

36 Ibid.

37 Abu Yahya Zakaria al Anshori. tt. Fathul Wahab. Beirut: Dâr al Fikri. hlm. 66

38 Ibn Rusyd. tt. Bidâyah al M ujtahid. Beirut: Dâr al Fikri. hlm. 50

\section{DAFTAR PUSTAKA}

A bdullah, Gani, Abdul. 1994. Pengantar Kompilasi Hukum Islam dalam Tata H ukum Indonesia. Jakarta: Gema Insani Pers.

Al Ansori, Zakaria, Abu Yahya. tt. Fathul Wahab. Beirut: Dâr al Fikri.

Al Bukhari. 1992. Shahîh Bukhâri. Beirut: Dâr al Kutub.

Al Sâyis, Ali, Muhammad. 2001. Tafsîr Ayât al Ahkâm. Beirut: Dâr al Ihya' al Turat al 'Arabi.

Al Shâbuni, Ali, Muhammad. 1997. Rawai'ul Bayân Tafsîr A yât al A hkâm min al Qur'an. Beirut: Dâr al Ihya.

Al Thabari, Abu Ja`ar Muhammad bin Jarir. 1978. Tafsîr al-Thabariy. Juz 4. Beirut: Dâl Fikri.

Al Zuhaili, Wahbah. 1984. Figh Islâm wa A dillatuhu. juz. IX. Damsik: Daar al Fikr.

Al-Harrasiy, Kiya. 1983. Ahkâm al-Quran. Jilid I. Beirut: Dâr al-Kitâb alIImiyyah.

Al-Jashash, A bu Bakar. tt. A hkâm al-Q uran. Beirut: Dâr al-Kitâb al-A rabi. 
Al-Qurthubiy, Abu Abdillah al-Anshariy. tt. Jami` al-Ahkâm al-Quran. jilid 8. Kairo Ar al-Kutub al-Arabiy

Al-Thabathaba'i, Muhammad Husein. tt: al-M izân fi Tafsîr al-Q uran, Beirut. alMuassasat al-Islamiy.

Al-Zarqaniy, Muhammad al-'A zhim. tt. M anâhil al-I rfân fi U lûm al-Q uran. Kairo: Isa al-Bab al-Halabiy

Departemen Agama RI. 1977. Al-Q ur'an dan Terjemahannya. Jakarta: Bumi Restu. Hayyan, Hayyan, al-Andalusi, A bu Yusuf, Muhammad. 1978. Tafsir al-Bahr alM uhîth. Jilid 3. Beirut: Dâr al Fikri.

Ibn Katsîr, al-Qurasyi al-Dimasqiy. tt. Tafsîr AI-Q uran al-A zhîm, jilid 2. Beirut. Dâr al-Andalus.

Ibn Rusyd. tt. Bidâyah al M ujtahid. Beirut: Daar al Fikri.

Munawwir, Warson, A hmad. 1997. al M unawwir. Surabaya: Pustaka Progressif. 1997

Ridha, Rasyid, Muhammad. tt. Tafsîr al-Quran al-H akîm. Kairo: Maktabat alQahiroh.

Umar, Nasharuddin. 2001. Argumen Kesetaraan Jender Perspektif al Qur'an. Jakarta: Paramida. 